\title{
The Dynamics of Mycobiota Development in Various Types of Wood Dust Depending on the Dust Storage Conditions
}

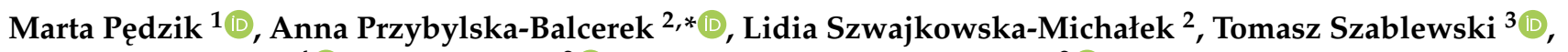

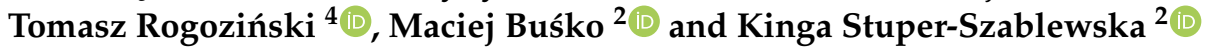 \\ 1 Łukasiewicz Research Network—Wood Technology Institute, Winiarska St. 1, 60-654 Poznan, Poland; \\ marta.pedzik@itd.lukasiewicz.gov.pl \\ 2 Department of Chemistry, Faculty of Forestry and Wood Technology, Poznan University of Life Sciences, \\ ul. Wojska Polskiego 75, 60-625 Poznan, Poland; lidia.szwajkowska@up.poznan.pl (L.S.-M.); \\ maciej.busko@up.poznan.pl (M.B.); kinga.stuper@up.poznan.pl (K.S.-S.) \\ 3 Department of Menegment of Food Quality and Safety, Poznan University of Life Sciences, \\ 60-637 Poznan, Poland; tomasz.szablewski@up.poznan.pl \\ 4 Department of Furniture Design, Faculty of Forestry and Wood Technology, Poznan University of Life Sciences, \\ Wojska Polskiego St. 38/42, 60-627 Poznan, Poland; tomasz.rogozinski@up.poznan.pl \\ * Correspondence: anna.przybylska@up.poznan.pl
}

check for updates

Citation: Pędzik, M.;

Przybylska-Balcerek, A.;

Szwajkowska-Michałek, L.;

Szablewski, T.; Rogoziński, T.;

Buśko, M.; Stuper-Szablewska, K.

The Dynamics of Mycobiota

Development in Various Types of

Wood Dust Depending on the Dust Storage Conditions. Forests 2021, 12,

1786. https://doi.org/10.3390/

f12121786

Academic Editors: Sabrina Palanti and Nasko Terziev

Received: 29 November 2021 Accepted: 13 December 2021

Published: 16 December 2021

Publisher's Note: MDPI stays neutral with regard to jurisdictional claims in published maps and institutional affiliations.

Copyright: (C) 2021 by the authors. Licensee MDPI, Basel, Switzerland. This article is an open access article distributed under the terms and conditions of the Creative Commons Attribution (CC BY) license (https:// creativecommons.org/licenses/by/ $4.0 /)$.

\begin{abstract}
Solid or processed wood, and wood waste in particular (dust, shavings, etc.) are the source of a number of health hazards for workers in the wood industry. One of the many negative health effects of exposure to fungi is allergic diseases caused by hypersensitivity reactions. The aim of this study was to investigate the effect of wood species and the degree of dust fragmentation, resulting from processing conditions and storage conditions on the level of wood dust contamination with microscopic fungi during 1 year of storage. An additional aspect of the research was the assessment of the influence of the antioxidant wood bioactive compounds on the development of $A$. alternata microscopic fungi. It was found that the conditions in which wood dust is stored significantly affect the development of microscopic fungi, especially fungi of the genus Alternaria. The results indicate that temperature is the determining factor, not the relative humidity of the air. The degree of dust fragmentation resulting from the sanding paper grit also has a significant impact on the development of microscopic fungi. Finer dust is more susceptible to the development of microscopic fungi. The antioxidant activity of the wood from which the dust was formed was found to have a significant impact on the development of microscopic fungi. An inverse relationship was observed, indicating the strong activity of antimicrobial substances. Gaining comprehensive knowledge of how all factors affect each other is a key step in understanding the risk and implementing measures to prevent and protect the work environment.
\end{abstract}

Keywords: wood dust; microscopic fungi; antioxidant activity; ergosterol; ABTS

\section{Introduction}

Alternaria alternata (Fr.) Keissl. is a fungus species belonging to the phylum Ascomycota, in the class Dothideomycetes. They are ubiquitous organisms that can develop on various surfaces. The optimal conditions for their development are high humidity and temperature. The development of the thallus and the release of spores lead to colonization of the surface. The consequence of this is the presence of both spores and fragments of hyphae in the air surrounding the affected surfaces. These components of mushroom biomass are part of dust $[1,2]$.

Hypersensitivity is a pathological and qualitatively altered tissue reaction caused by repeated exposure to antigens. It consists of the development of an immune reaction related to the formation of specific antibodies or sensitized lymphocytes. As a result, there may be a very strong response of both the cellular and humoral type, and in extreme cases 
even the destruction of one's own cells. One of the many negative health effects of exposure to fungi is allergic diseases caused by hypersensitivity reactions. Fungal spores are among the most abundantly represented biological particles in the atmospheric air. They are much more numerous than the pollen grains of other environmental allergens. Due to their small size, the spores enter the respiratory tract with the inhaled air $[3,4]$. The diagnosis of allergies and fungal diseases is difficult due to the clinical picture of the disease. In addition, most patients are hypersensitive to several species of these pathogens, which may be due to both independent allergies to more than one allergen, and the presence of cross-allergies [5-7]. An important feature of hypersensitivity to allergens in the form of particles of fungal biomass is the variability of the biochemical and allergenic properties of fungi from different populations, even within species, which is related to their unlimited adaptability to environmental conditions [8-11].

Solid or processed wood, and wood waste in particular (dust, shavings, etc.), are the source of a number of health hazards for workers in the wood industry. The number of workers exposed to wood dust in contemporary Poland was estimated at approximately 310,000 for the years 2000-2003; 79,000 workers were exposed to an LO concentration of $5 \mathrm{mg} / \mathrm{m}^{3}, 52,000$ to a concentration of $0.5-1 \mathrm{mg} / \mathrm{m}^{3}, 63,000$ to a concentration of $1-2 \mathrm{mg} / \mathrm{m}^{3}$, 72,000 to a concentration of $2-5 \mathrm{mg} / \mathrm{m}^{3}$ and approximately 44,000 to a concentration above $5 \mathrm{mg} / \mathrm{m}^{3}$ [12-18].

Sanding, sawing, milling and drilling wood materials are among the most dustgenerating processes in the wood industry. The automation of processing is particularly related to the high emission of dust pollutants. The most disadvantageous is the use of machines with high rotational speed [17-21]. The greater the speed of the tool during machining, the greater the generation of heat in the tool [22]. The thermal properties may vary not only depending on the modification method, but also the material's density and thickness [23]. There are visible differences between the density of modified and native beech wood. Higher density provides better thermal conductivity, which is especially important when using these raw materials for flooring, but undesirable in industrial processing $[16,18,24]$. In turn, thermal modification may contribute to the formation of a greater number of fine fractions, depending on the type of processing (e.g., during milling) $[13,25,26]$. The exposure of workers to dust from deciduous trees (hardwood) or in mixture with conifers (softwood) is correlated with the occurrence of occupational diseases. An additional factor increasing the undesirable effect of dust is the presence of organic particles-mainly microscopic fungi, and to a lesser extent bacteria $[27,28]$. Taking into account the health effects and the socio-economic conditions presented by the European Commission, the NDS (maximum permissible concentration) was changed from $3 \mathrm{mg} / \mathrm{m}^{3}$ to $2 \mathrm{mg} / \mathrm{m}^{3}$ for the respirable dust fraction. Wood dusts are carcinogenic, mutagenic and dust-generating (according to Directive 2017/2398/EC) [28]. Numerous scientific studies prove the high danger posed by long-term contact with wood dust. Most of this research, however, focuses on fire hazards and the effects of temperatures that can ignite a dust mixture both in the air and on utility surfaces. Another significant risk factor is the temperature increase caused by the work of tools that are in direct contact with chips and dust, which can lead to ignition. Another issue is that long-term exposure to dust and dust in humid conditions degrades wood materials, resulting in discoloration and an unfavorable change in the color of wood and wood-based materials [28-31].

Another group of studies is devoted to the analysis of the quantity and size of dust particles formed during processing, which are respirable fractions (i.e., the most hazardous to health) [30,31]. The dust of all tree species have been classified as carcinogenic to humans (Group 1) by the International Agency for Research on Cancer (IARC) (IARC, 2012) [30]. Such activities lead to the extension of research in the understanding and comprehensive assessment of the harmfulness of dusts of individual tree species subjected to mechanical treatment. In addition, growing microorganisms pose an additional health risk. Therefore, it becomes important to examine the effect of the variable content of bioactive compounds contained in individual wood species. Comprehensive knowledge and understanding 
of the risk is a key step in introducing risk prevention and protection measures in the work environment [31,32]. The basis of this research is the risk related to the occurrence of dust and the possibility of the development of microscopic fungi in the dust deposited in workplaces.

The aim of this study was to investigate the effect of wood species and the degree of dust fragmentation resulting from processing conditions and storage conditions on the level of wood dust contamination with microscopic fungi during 1 year of storage. An additional aspect of the research was the assessment of the influence of the antioxidant wood bioactive compounds on the development of $A$. alternata microscopic fungi.

\section{Materials and Methods}

\subsection{Preparation of Dust}

Six hardwood species (black alder, European ash, common walnut, pedunculate oak, hornbeam, European beech) and three softwood species (larch, pine, and spruce) were studied. The wood was kiln-dried to $8 \% \pm 1 \%$ moisture content, then specimens with a sanded surface of $150 \mathrm{~mm} \times 80 \mathrm{~mm}$ were prepared.

Sanding was performed using a prototype narrow-belt sanding machine designed and made in the laboratory of the Department of Furniture Design (Faculty of Wood Technology, Poznań University of Life Sciences (PULS)). EKA 1000 F (Ekamant, Poznan, Poland) sanding paper in the form of belts with dimensions $1000 \mathrm{~mm} \times 80 \mathrm{~mm}$ was used. The grits of the paper were P60 and P180. A sanding belt speed of $14.5 \mathrm{~m} . \mathrm{s}^{-1}$ and a sanding pressure of $0.65 \mathrm{~N} . \mathrm{cm}^{-2}$ were applied. The dust created during sanding was collected using a multi-purpose vacuum cleaner of the type NT 30/1 Tact (Alfred Kärcher SE \& Co. KG, Winnenden, Germany) connected to the working zone. The sanding process has already been described in the literature [33].

\subsection{Preparation of the Inoculum of Microscopic Fungi}

A yeast extract-sucrose (YES) agar medium was used in this study. Alterneria alternata isolates were incubated on the agar medium for approximately 4 weeks. The contents of the plates were washed with saline to obtain a spore suspension. The concentration of the spore suspensions of the individual isolates was adjusted to approximately $5 \times 10^{5}$ spores $/ \mathrm{mL}$ using the hematocrit. The suspensions were mixed in equal proportions. The dust material was brought to a constant weight by drying at $40^{\circ} \mathrm{C}$. Then it was sprayed with a spore suspension in the amount of about $10 \mathrm{~mL}$ of suspension per $100 \mathrm{~g}$ of dust.

\subsection{Dust Storage Conditions}

The inoculated dust samples were stored for 1 year in controlled temperature and relative humidity chambers. The combinations of air relative humidity and temperature presented in Table 1 were selected for the experiment. The dust storage conditions were selected on the basis of the optimal growth parameters of microscopic fungi of the genus Alternaria: $20^{\circ} \mathrm{C}$ and $90 \%$ air relative humidity. In order to determine which factor (humidity or temperature) influences the growth of mycobiota, several variants (also unfavorable for the development of microscopic fungi) were examined, as presented in Table 1 [34].

Table 1. Variants of dust storage conditions.

\begin{tabular}{ccc}
\hline Variant No. & Temperature $\left({ }^{\circ} \mathbf{C}\right)$ & Air Relative Humidity (\%) \\
\hline 1 & 20 & 40 \\
\hline 2 & 20 & 90 \\
\hline 3 & 6 & 40 \\
\hline 4 & 6 & 90 \\
\hline
\end{tabular}




\subsection{Ergosterol Analysis}

Samples were analyzed for the presence of ergosterol (ERG) according to StuperSzablewska et al. (2017) [33]. Briefly, samples of $100 \mathrm{mg}$ were placed into culture tubes, suspended in methanol, treated with $2 \mathrm{M}$ aqueous $\mathrm{NaOH}$ and sealed tightly. Samples were irradiated $(370 \mathrm{~W})$ for $20 \mathrm{~s}$, after $5 \mathrm{~min}$ for additional $20 \mathrm{~s}$ and extracted with pentane $(3 \times 4 \mathrm{~mL})$ within the culture tubes. The combined pentane extracts were evaporated to dryness in a gentle stream of high-purity nitrogen. Prior to analysis, samples were dissolved in $4 \mathrm{~mL}$ of methanol, filtered through $13 \mathrm{~mm}$ syringe filters with $0.5 \mu \mathrm{m}$ pore diameter, evaporated to dryness in a stream of nitrogen and dissolved in $1 \mathrm{~mL}$ of methanol. Chromatographic separation was performed on a Acquity H class UPLC system equipped with a Waters Acquity PDA detector (Milford, MA, USA). The chromatographic separation was performed on an Acquity UPLC ${ }^{\circledR}$ BEH C18 column (Watersy, Dublin, Ireland) $(100 \mathrm{~mm} \times 2.1 \mathrm{~mm}$, particle size $1.7 \mu \mathrm{m})$ (Watersy, Dublin, Ireland) and eluted with methanol/acetonitrile/water (85:10:5) at a flow rate of $0.4 \mathrm{~mL} / \mathrm{min}$. Ergosterol was detected with a Waters Acquity PDA detector (Waters, Milford, MA, USA) set at $282 \mathrm{~nm}$. The presence of ERG was confirmed by a comparison of retention times and by co-injection of every tenth sample with an ergosterol standard [32,35-37]. Determining ERG levels was also the subject of household dust studies in which dust from a dust bag was grown to determine the types of fungi formed there, and seasonal variability of conditions was observed with respect to its concentration level. Household dust, through the mechanisms of settling and re-suspending dust in the air, is an exposure to the inhalation of harmful particles along with microorganisms, as are the particles of wood dust in wood processing plants.

\subsection{ABTS $^{\bullet+}$ Method}

For ABTS ${ }^{\bullet+}$ generation from ABTS salt, $3 \mathrm{mM}$ of $\mathrm{K}_{2} \mathrm{~S}_{2} \mathrm{O}_{8}$ was reacted with $8 \mathrm{mM}$ ABTS salt in distilled, deionized water for $16 \mathrm{~h}$ at room temperature in the dark. The ABTS ${ }^{\bullet+}$ solution was then diluted with a $\mathrm{pH} 7.4$ phosphate buffer solution containing $150 \mathrm{mM}$ $\mathrm{NaCl}$ (PBS) to obtain an initial absorbance of 1.5 at $730 \mathrm{~nm}$. A fresh ABTS ${ }^{\bullet+}$ solution was prepared for each analysis. Reaction kinetics was determined over a $2 \mathrm{~h}$ period with readings every $15 \mathrm{~min}$. Reactions were complete in $30 \mathrm{~min}$. Samples and standards (100 $\mu \mathrm{m})$ were reacted with the ABTS ${ }^{\bullet+}$ solution $(2900 \mu \mathrm{m})$ for $30 \mathrm{~min}$. Trolox was used as a standard. Results were expressed in ABTS ${ }^{\bullet+}(\mu \mathrm{mol}$ TROLOX/kg) d.m. sample [32,35-37].

\section{Results and Discussion}

The conducted research was aimed at verifying the hypothesis that the growing of mycobiota in wood dust is influenced by:

1. The conditions in which the wood dust was produced;

2. Dust decomposition degree resulting from processing parameters;

3. Antioxidant activity of the wood from which the dust was formed.

For this purpose, model tests were carried out on dust from various types of wood produced during machine sanding. The level of contamination by microscopic fungi was investigated using the analysis of ergosterol concentration. It is a sterol characteristic for the mycobiotic cell membrane, and the assessment of its content is used as a marker for quantifying the level of fungal contamination of various materials [35-37].

The conducted research and the literature on the subject indicate that the biotic components of wood, especially those of an antioxidant nature, have a significant impact on the growth dynamics of microscopic fungi [35-37]. In the conducted research, the antioxidant activity of extracts obtained from dusts was analyzed using the reaction with the radical ABTS. Samples of tested dusts with different particle sizes resulting from sanding using sanding papers with two grits were stored for a year in various conditions of temperature and air relative humidity. Apart from the storage parameters and dust particle size, the variable in the experiment was the level of dust contamination by mycobiota. The control samples were characterized by a natural level of mycobiotic contamination, while 
the second test variant was samples additionally infected with Alternaria alternata spores isolated from wood.

The results of the dynamics of mycobiota growth depending on the storage conditions and the dust particle size for control and inoculated (additionally infected) samples are presented in Figure 1.

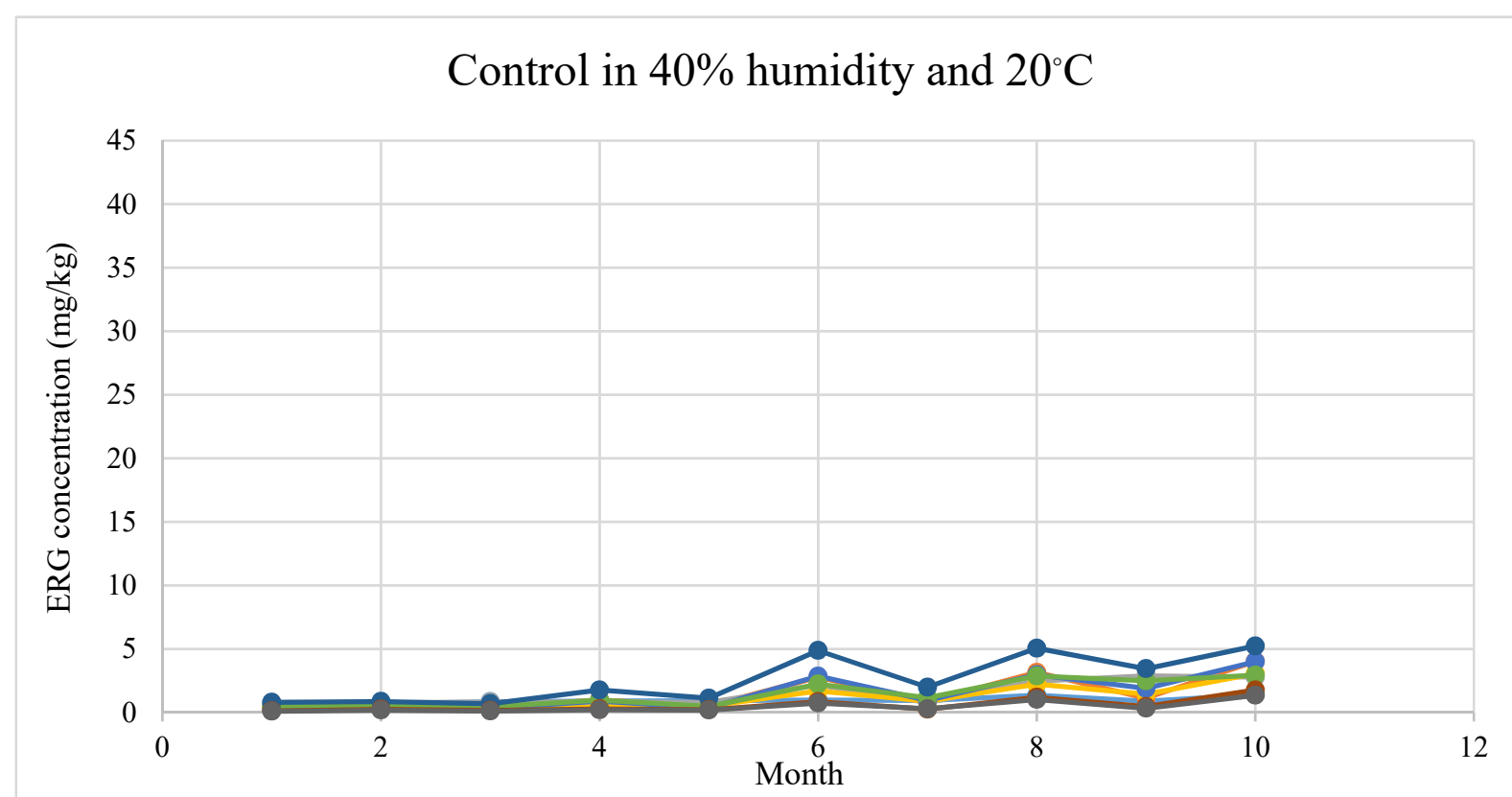

European Beech, Pedunculate Oak, Hornbeam, European Ash, Black Alder, Common Walnut, Larch, Pine, Spruce
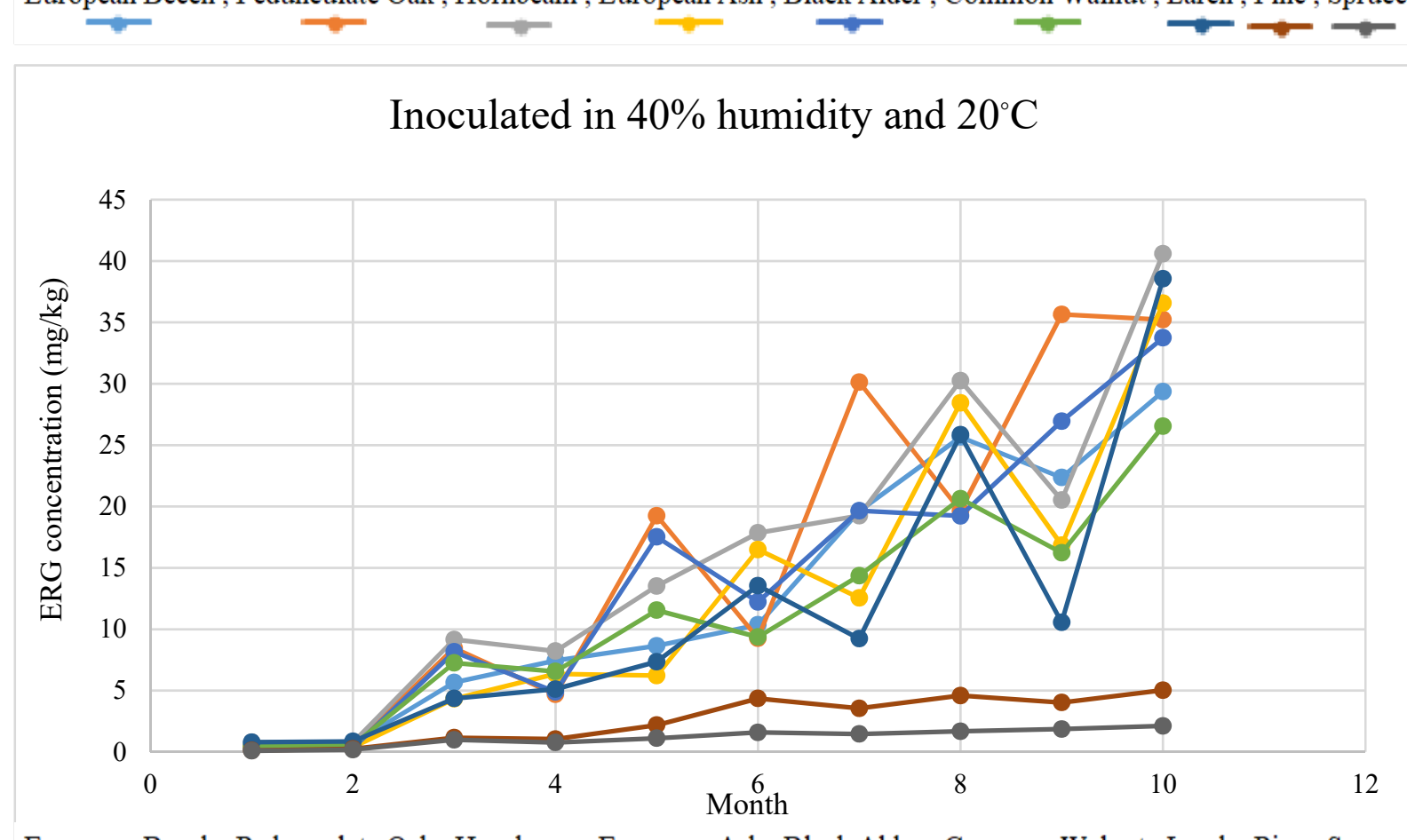

European Beech, Pedunculate Oak, Hornbeam, European Ash, Black Alder, Common Walnut , Larch, Pine, Spruce

(Variant No. 1)

Figure 1. Cont. 


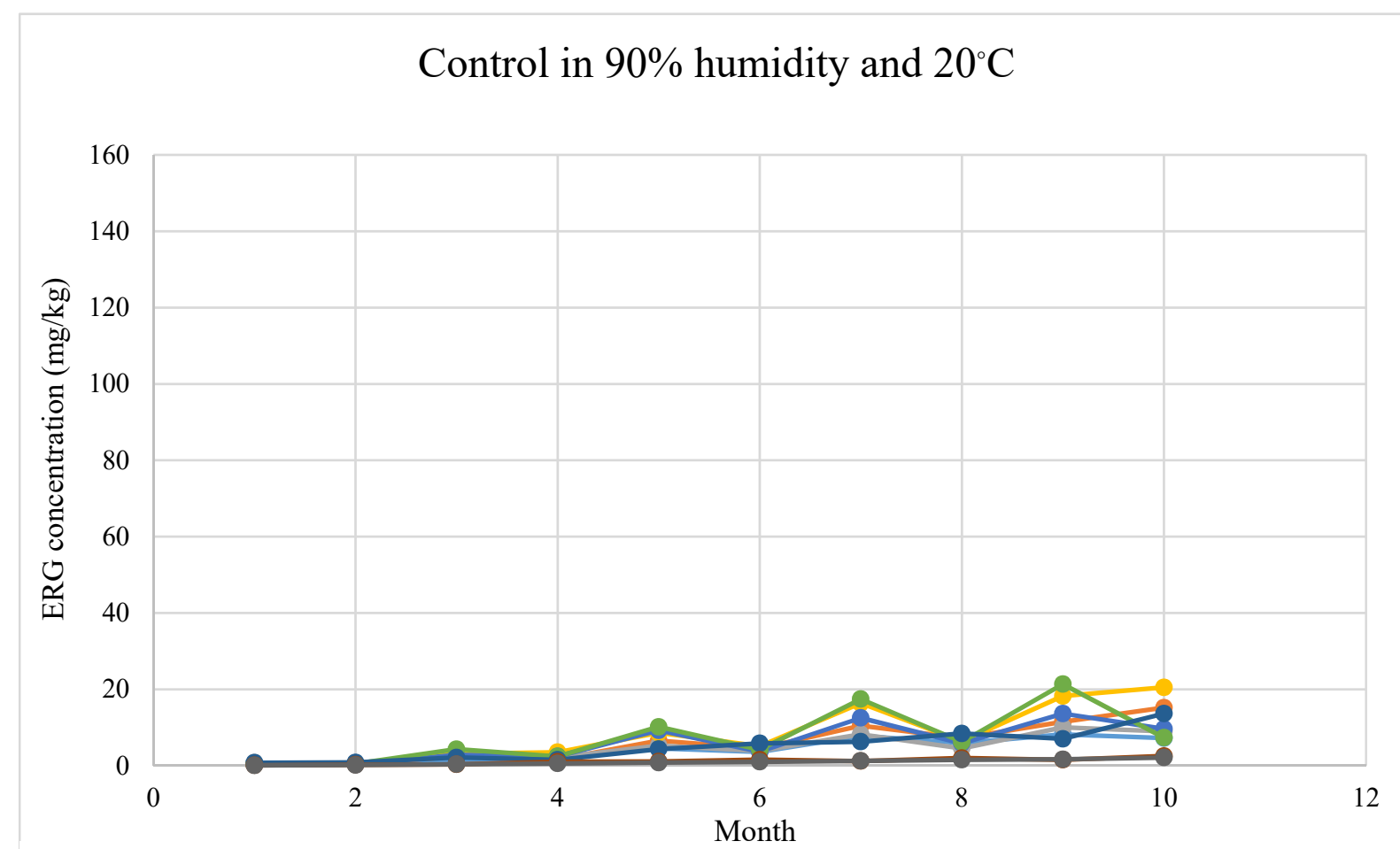

European Beech, Pedunculate Oak, Hornbeam, European Ash, Black Alder, Common Walnut, Larch, Pine, Spruce

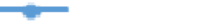

\section{Inoculated in $90 \%$ humidity and $20^{\circ} \mathrm{C}$}

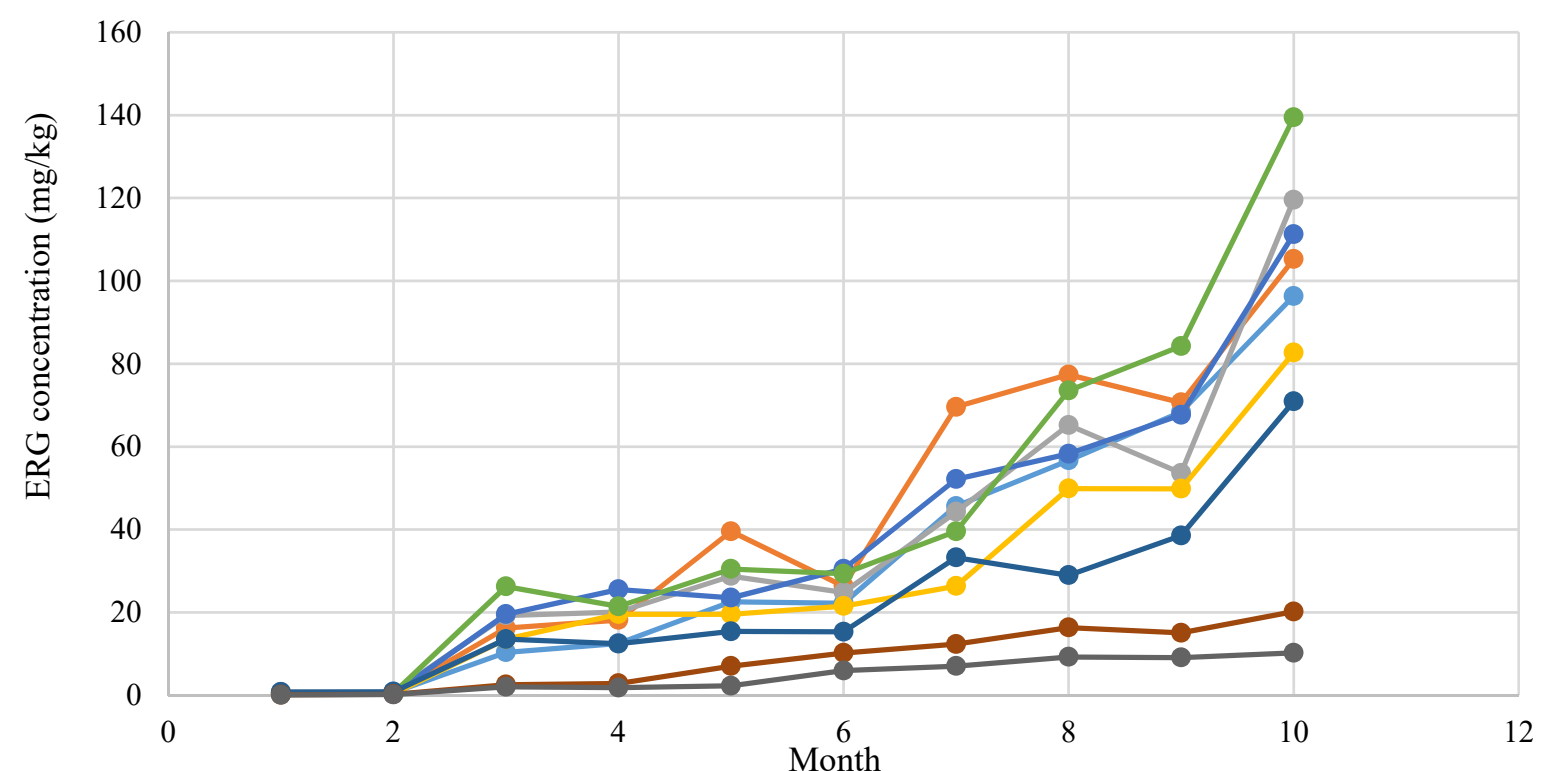

European Beech, Pedunculate Oak, Hornbeam, European Ash, Black Alder, Common Walnut, Larch, Pine, Spruce (Variant No. 2)

Figure 1. Cont. 


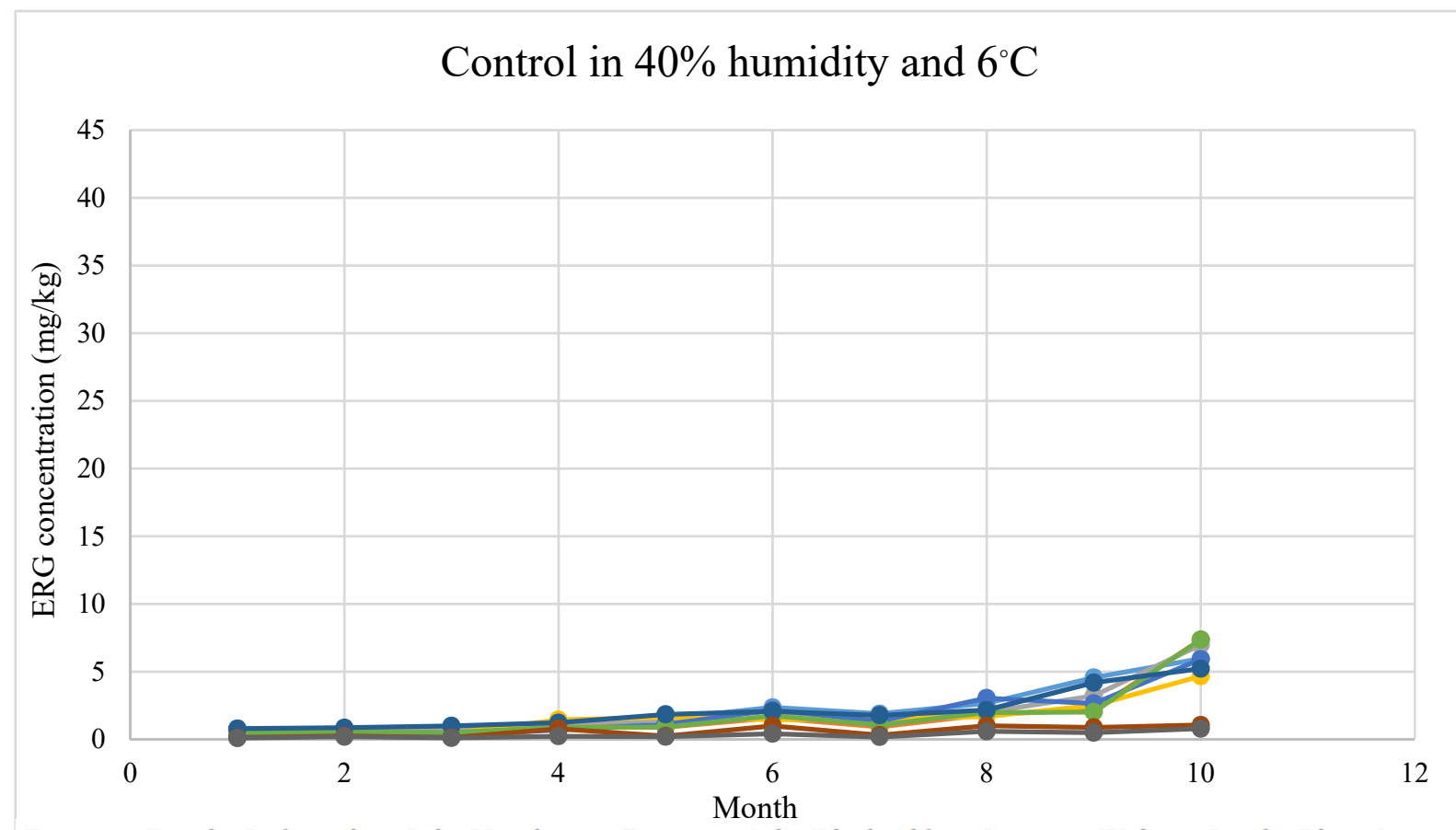

European Beech, Pedunculate Oak, Hornbeam, European Ash, Black Alder, Common Walnut, Larch, Pine, Spruce

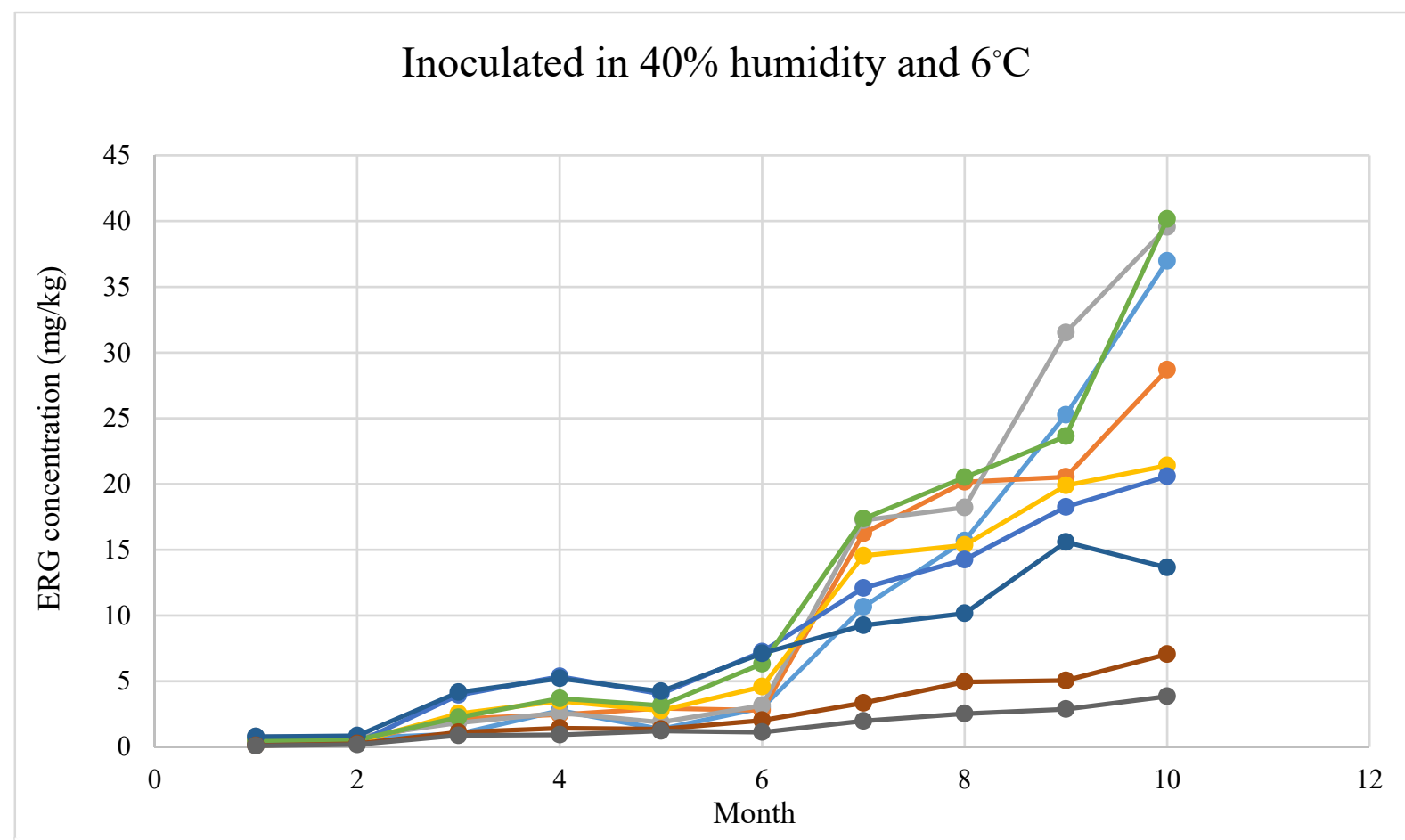

European Beech, Pedunculate Oak, Hornbeam, European Ash, Black Alder, Common Walnut, Larch, Pine, Spruce (Variant No. 3)

Figure 1. Cont. 


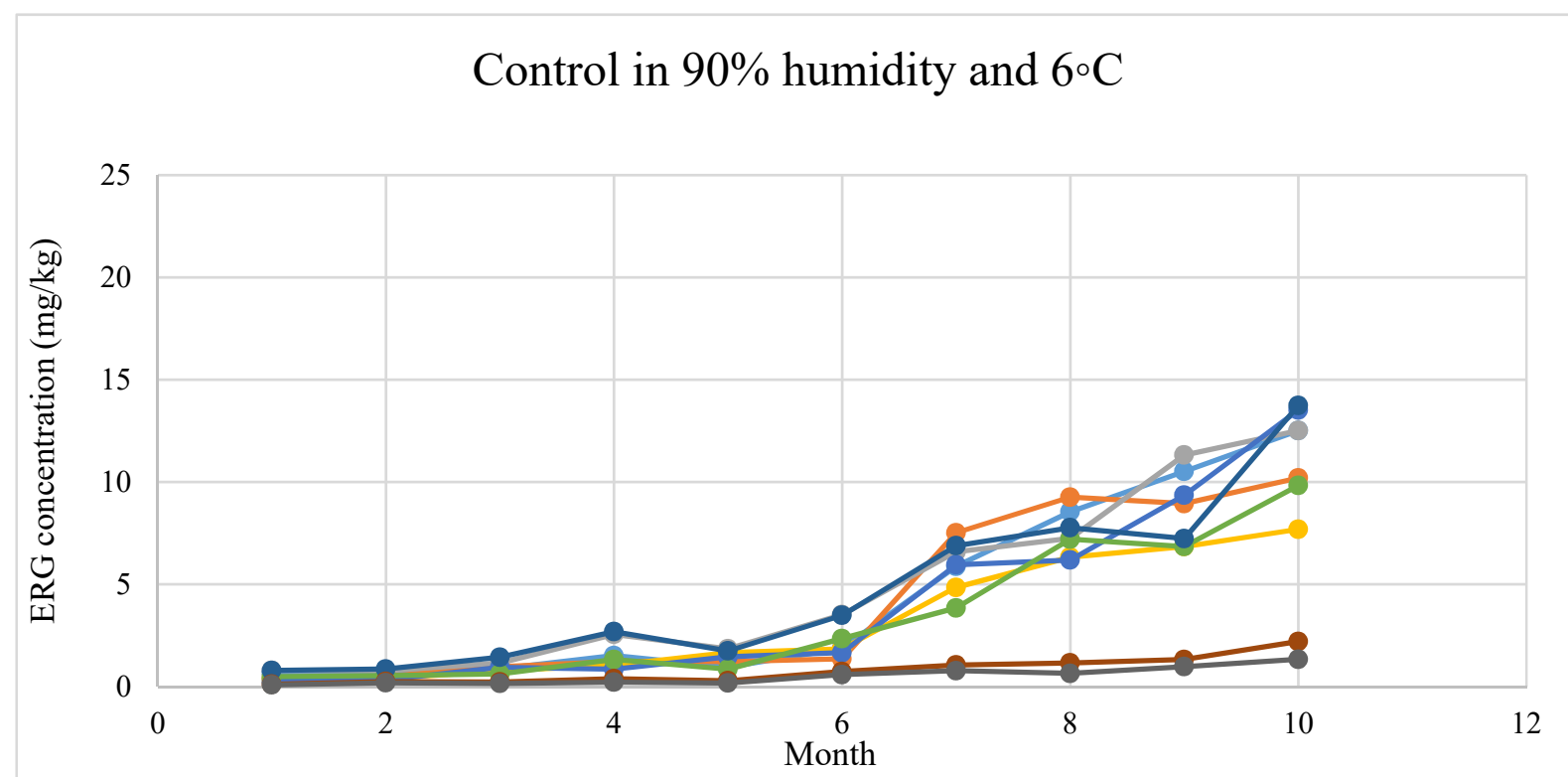

European Beech, Pedunculate Oak, Hornbeam, European Ash , Black Alder, Common Walnut , Larch , Pine , Spruce

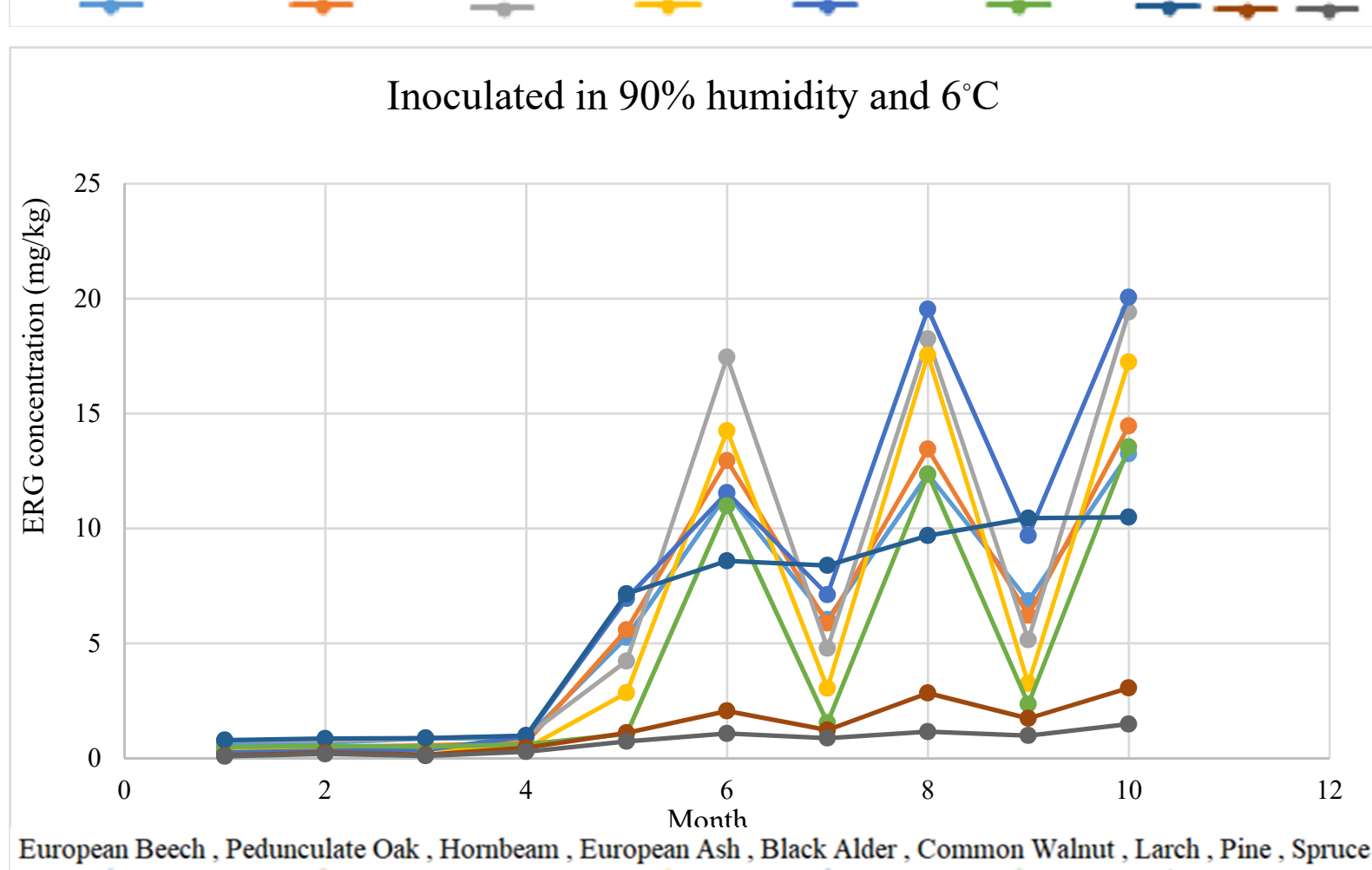

European Beech, Pedunculate Oak, Hornbeam, European Ash, Black Alder, Common Walnut, Larch, Pine, Spruce

(Variant No. 4)

Figure 1. Dynamics of changes in ERG concentration in the dust of various wood species depending on the storage conditions.

Linear growth of the mycobiota over time was found for all sample variants. Moreover, a significantly higher concentration of ERG (i.e., up to 10 times higher) was found in the dust inoculated with A. alternata compared to the samples naturally contaminated with microscopic fungi (control). Increased air temperature and humidity favored the growth of mycobiota. In the case of dusts with smaller particle size, formed during sanding with P180 sanding paper, it was found that mycobiota developed more intensively, as evidenced by a higher concentration of ERG. While analyzing the influence of storage conditions on 
the development of microscopic fungi, it was found that the dynamic development of the samples of dust inoculated with $A$. alternata during the year was influenced by temperature. A significantly higher concentration of ERG was observed in the dust samples stored at $20^{\circ} \mathrm{C}$ compared to those stored at $6{ }^{\circ} \mathrm{C}$, and the trend was the same for dust created during sanding with both papers (P60 and P180). In the conditions of $90 \%$ air relative humidity and $20{ }^{\circ} \mathrm{C}$ temperature, a significant increase in the amount of microscopic fungi (measured by the concentration of ERG) was observed in comparison to the control dust samples-a 10-fold increase was observed for dust created during sanding with sanding paper of grit P180 and a 5-fold increase was observed for dust created with P60 sanding paper. Comparing the results in the control dust and inoculated dust samples stored at $90 \%$ and $6{ }^{\circ} \mathrm{C}$, the ERG concentration values were 8 and 10 times lower for the dusts created with papers with grits P180 and P60, respectively. Summing up, the changes in ERG concentration indicated a significant influence of temperature on the development of microscopic fungi, especially A. alternata.

The second experimental factor was the dust particle size, the influence of which on the level of ERG concentration was investigated. In the case of the dust created during sanding with sanding paper with P180 grit, a significantly higher concentration of ERG was found compared to the dust created with the P60 paper, on average twice for all analyzed samples. Thus, it was found that the finer the dust, the more dynamic the growth of microscopic fungi (Figure 2).

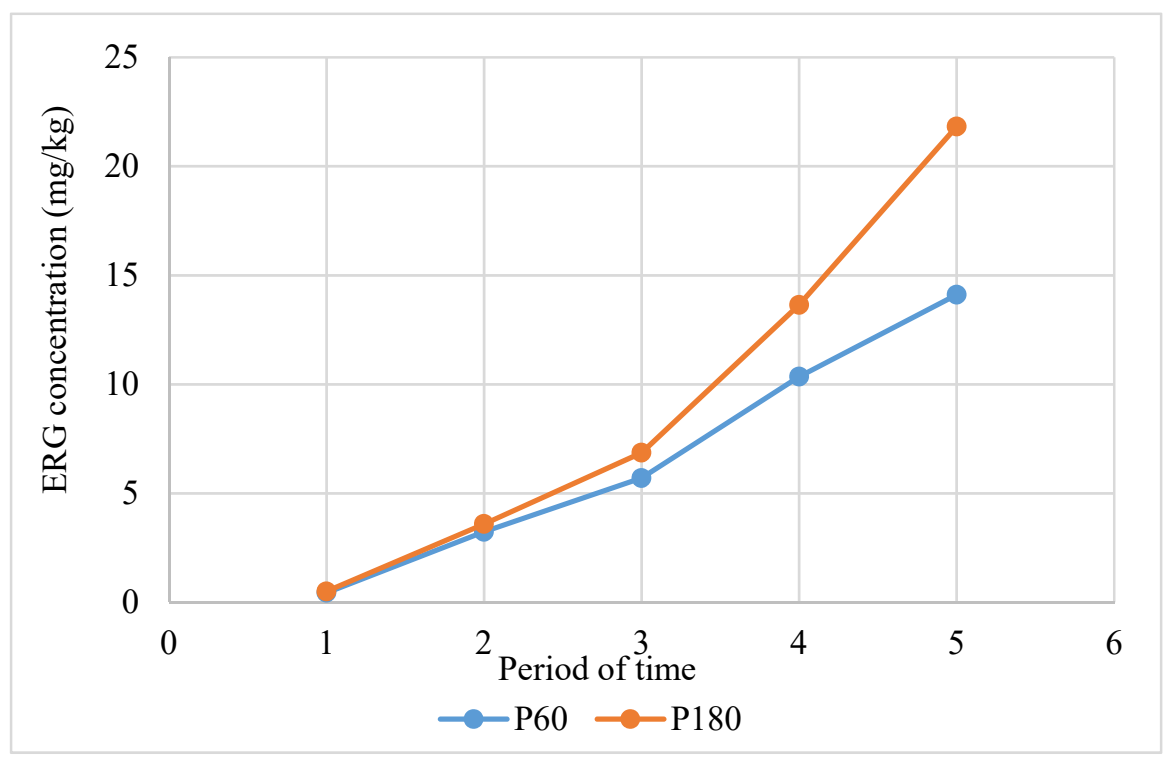

Figure 2. Dynamics of microscopic fungi development measured with ERG concentration (mg/ $\mathrm{kg}$ ) for averaged results depending on the dust particle size.

The growth of microscopic fungi, and wood pathogens in particular, is one of the stressors. Previous research and literature reports indicate that substances contained in wood cells belonging to the group of low-molecular-weight antioxidants fulfill their role even after cutting a tree and subjecting its wood to technological treatment. In this study, the antioxidant activity of wood dust extracts was analyzed at the same time as ERG analysis was performed. A significant inverse relationship was found between the ERG concentration and the antioxidant activity measured by the reaction with the radical $\mathrm{ABTS}^{\bullet+}$ (Table 2). 
Table 2. Correlation coefficient of ERG/ABTS ${ }^{\bullet+}$.

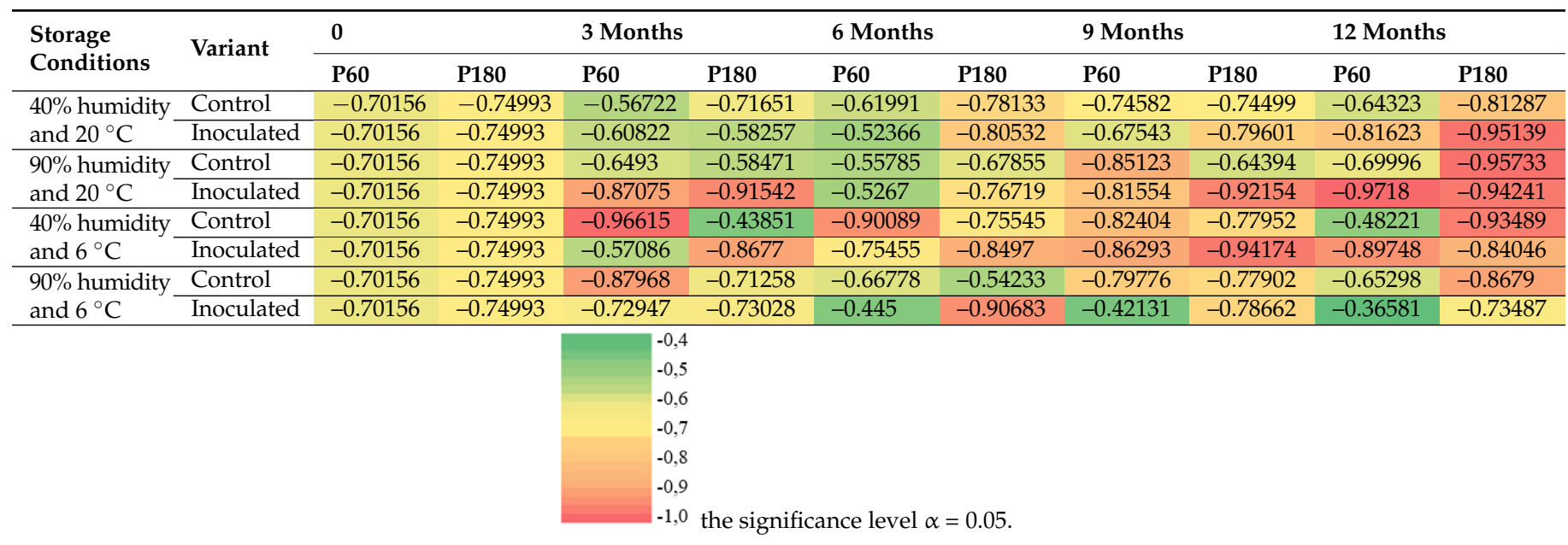

Results recorded in the course of the conducted chemical analyses were subjected to statistical analysis with the use of STATISTICA v. 13.3 software. The correlation matrix between ergosterol (ERG) concentration and antioxidant activity, measured by the reaction with the radical ABTS, was determined on the basis of the Pearson linear correlation coefficient at the significance level $\alpha=0.05$.

This means that the greater the activity of antioxidants or their compounds, the slower the development of microscopic fungi or its inhibition. Antioxidant compounds also showed antimicrobial activity. So far, this phenomenon has not been described in the literature for wood, or for dust. Some types of wood were characterized by higher activity, which was correlated with lower activity of microscopic fungi and their slower growth. The results indicate that the resistance mechanisms of wood were active even after technological processing.

\section{Discussion}

The type of research presented in this paper has not been conducted so far in terms of the relationship between antioxidant activity, dynamics of microscopic fungi growth, dust particle size and dust storage conditions. The level of dust contamination with microscopic fungi, expressed as ERG concentration, is a characteristic quantity for the type of wood and correlated with the biomass of microscopic fungi. In the case of antioxidant activity, studies have so far been carried out on other organic raw materials, such as grain or straw. These studies showed significant differences between the types of raw materials [38-40], which is inextricably linked with the qualitative and quantitative profile of antioxidant bioactive compounds. This research aimed to determine the dependence of the development of microscopic fungi as a function of antioxidant activity in the raw material (i.e., wood dust), representing an original and innovative approach. The relationship between these parameters is known for raw materials other than wood [41-44]. There was a significant positive correlation between the concentration of antioxidant compounds and the antioxidant activity measured by the reaction with the radical ABTS [36-38]. Along with the growth of microscopic fungi, the defense mechanisms of wood dust are activated in the form of the release of low-molecular-weight antioxidants from cells and their introduction into the metabolism of microscopic fungi [45-48]. This leads to growth inhibition, which was observed in our studies as a decrease in ERG levels. Similar results were obtained by Szablewski et al. (2021) [41]. At the same time, an increase in the antioxidant activity of the test system was observed. On the other hand, if the activity or amount of antioxidant compounds was too low, microscopic fungi grew significantly. 


\section{Conclusions}

It was found that the conditions (humidity and temperature) in which wood dust was stored significantly affected the development of microscopic fungi, especially fungi of the genus Alternaria. Temperature was the more important determining factor, followed by the air relative humidity. The degree of dust fragmentation resulting from the sanding paper grit also had a significant impact on the development of microscopic fungi. Finer dust was more susceptible to the development of microscopic fungi. The antioxidant activity of the wood from which the dust was formed had a significant impact on the development of microscopic fungi. The effect of the antioxidant activity of wood, especially wood dust, has not previously been studied in terms of limiting the growth of microscopic fungi. The obtained results indicate the activity of low-molecular-weight antioxidants in wood/wood dust even when the tree metabolism is not active. Indeed, an inverse relationship was observed, indicating the strong activity of antimicrobial substances.

Author Contributions: Conceptualization, M.P. and T.R.; Formal analysis, M.P.; Funding acquisition, T.R.; Investigation, M.P.; Methodology, A.P.-B., L.S.-M., T.S. and M.B.; Project administration, K.S.-S.; Resources, M.P.; Software, T.R.; Visualization, K.S.-S.; Writing—original draft, M.P., L.S.-M. and T.S.; Writing-review \& editing, A.P.-B., T.R. and K.S.-S. All authors have read and agreed to the published version of the manuscript.

Funding: This research was funded by the funding for statutory R\&D activities as the research task No. 506.272.02.00 and 506.227.02.00 of the Faculty of Forestry and Wood Technology, Poznań University of Life Sciences.

Institutional Review Board Statement: Not applicable.

Informed Consent Statement: Not applicable.

Data Availability Statement: Department of Furniture Design, Faculty of Forestry and Wood Technology, Poznan University of Life Sciences, Wojska Polskiego St. 38/42, 60-627 Poznan, Poland; tomasz.rogozinski@up.poznan.pl.

Conflicts of Interest: The authors declare no conflict of interest.

\section{References}

1. Ogórek, R.; Pląskowska, E.; Kalinowska, K. Characteristics and taxonomy of fungi of the genus Alternaria. Mikologia Lekarska 2011, 18, 150-155.

2. Lipiec, A.; Rapiejko, P. Alternaria alternata-Aerobiology. Characteristics of allergens and biological aspect. Alergia 2005, 2, 39-42.

3. Brown, W.D. Mould allergy affecting the ears, nose and throat. Otolaryng. Clin. N. Amer. 1971, 4, 3.

4. Lacey, J. Fungi and Actinomycetes as allergen. In Allergy and Allergic Diseases; Kay, A.B., Ed.; Blackwell Science: London, UK, 1997.

5. Zgorzelska-Kowalik, J.; Wiszniewska, M.; Kowalik, D. Cross-reacting carbohydrate determinants in the diagnosis of occupational allergy. Med. Prakt 2010, 61, 79-89.

6. Batard, T.; Baron-Bodo, V.; Martelet, A.; Le Mignon, M.; Lemoine, P. Patterns of IgE sensitization in house dust mite-allergic patients: Implications for allergen immunotherapy. Allergy Wiley 2015, 71, 220-229. [CrossRef] [PubMed]

7. Buczyłko, K.; Majsiak, E. Selected cross-reactions in allergies of the upper respiratory and alimentary tract. Alergologia Polska 2017, 4, 139-145.

8. Lipiec, A. Mould hypersensitivity in patients suffering from allergic rhinitis. Otolaryngol. Pol. 2000, 54, 89-90.

9. Semik-Orzech, A.; Barczyk, A.; Pierzchała, W. The influence of sensitivity to fungal allergens on the development and course of allergic diseases of the respiratory tract. Pneumonol. Alergol. Pol. 2008, 761, 29-36.

10. Grinn-Gofron, A. Types of Aspergillus and Penicillium as a source of potential mushroom allergens. Alergoprofil 2010, 6, 2-5.

11. Knutsen, A.P.; Bush, R.K.; Demain, J.G.; Denning, D.W.; Dixit, A.; Fairs, A.; Greenberger, P.A.; Kariuki, B.; Kita, H.; Kurup, V.P.; et al. Fungi and allergic lower respiratory tract diseases. J. Allergy Clin. Immunol. 2012, 129, 280-291. [CrossRef]

12. Pakulska, D.; Soćko, R.; Szymczak, W. Wood dust-Inhalable fraction. Documentation of proposed occupational exposure limit values. Podstawy i Metody Oceny Środowiska Pracy 2017, 3, 17-93. [CrossRef]

13. Wiszniewska, M.; Walusiak, J.; Gutarowska, B.; Żakowska, Z.; Pałczyński, C. Mold fungi in the communal environment and in the workplace-A significant health hazard. Medycyna Pracy 2004, 55, 257-266.

14. Skowroń, J. Priority: Safe working conditions. Medycyna Pracy 2019, 70, 497-509. [CrossRef]

15. Dz, U. Dz, U. 2011 nr 33, poz. 166. Regulation of the Minister of Health of February 2, 2011 on tests and measurements of factors harmful to health in the work environment. Journal of Laws 2011 No. 2011 No.33, item. 166. Available online: http:/ /isap.sejm.gov.pl/isap.nsf/DocDetails.xsp?id=WDU20110330166 (accessed on 10 December 2021). 
16. Dz, U. 2016, poz. 1117. Announcement of the Minister of Health of 11 July 2016 on the publication of the uniform text of the Regulation of the Minister of Health on chemical substances, mixtures, agents or technological processes with carcinogenic or mutagenic effects in the work environment, Journal of Laws No. 2016 item 1117. Available online: http://isap.sejm.gov.pl/isap. nsf/DocDetails.xsp?id=WDU20160001117 (accessed on 10 December 2021).

17. Dutkiewicz, J.; Prażmo, Z. Biological factors of occupational hazards in the wood industry. Zdr. Publ. 2008, 118, 138-144.

18. Mackiewicz, B. Organic dust in the work environment and its impact on the human body, biological factors-Work safety. $B P$ 2014, 4, 24-32.

19. Koradecka, D.; Skowron, J. The activities of the Interministerial Commission for the Maximum Allowable Concentrations and Intensities of Factors Harmful to Health in the Work Environment in 2014-2016. Podstawy i Metod. Oceny Sr. Pr. 2016, 4, 5-39.

20. Mračková, E.; Krišt'ák, L'; Kučerka, M.; Gaff, M.; Gajtanska, M. Creation of Wood Dust during Wood Processing: Size Analysis, Dust Separation, and Occupational Health. BioResources 2015, 11, 209-222. [CrossRef]

21. Očkajová, A.; Kučerka, M.; Krišt'ák, L.; Ružiak, I.; Gaff, M. Efficiency of Sanding Belts for Beech and Oak Sanding. BioResources 2016, 11, 5242-5254. [CrossRef]

22. Hrčka, R.; Babiak, M. Some non-traditional factors influencing thermal properties of wood. Wood Res. 2012, 57, 367-374.

23. Troppová, E.; Tippner, J.; Hrčka, R.; Halachan, P. Qasi-stationary measurements of lignamon thermal properties. Bioresources 2013, 8, 6288-6296. [CrossRef]

24. Igaz, R.; Kminiak, R.; Krišt'ák, L'.; Němec, M.; Gerge', T. Methodology of Temperature Monitoring in the Process of CNC Machining of Solid Wood. Sustainability 2019, 11, 95. [CrossRef]

25. Hlásková, L.; Prochazka, J.; Novák, V.; Cermak, P.; Kopecký, Z. Interaction between Thermal Modification Temperature of Spruce Wood and the Cutting and Fracture Parameters. Materials 2021, 14, 6218. [CrossRef] [PubMed]

26. Sandak, J.; Goli, G.; Cetera, P.; Sandak, A.; Cavalli, A.; Todaro, L. Machinability of Minor Wooden Species before and after Modification with Thermo-Vacuum Technology. Materials 2017, 10, 121. [CrossRef]

27. Pałczyński, C.; Wiszniewska, M.; Szulc, B.; Walusiak, J. Occupational exposure to mold fungi-Case reports. Alergia 2008, 1, 28-31.

28. Soćko, R.; Pakulska, D.; Szymczak, W. Wood dust-Inhalable fraction Documentation of proposed values of occupational exposure limits (OELs). Podstawy i Metod. Oceny Sr. Pr. 2021, 2, 27-138.

29. Kubovský, I.; Oberhofnerová, E.; Kačík, F.; Pánek, M. Surface changes of selected hardwoods due to weather conditions. Forests 2018, 9, 557. [CrossRef]

30. Pędzik, M.; Rogoziński, T.; Majka, J.; Stuper-Szablewska, K.; Antov, P.; Kristak, L.; Kminiak, R.; Kučerka, M. Fine Dust Creation during Hardwood Machine Sanding. Appl. Sci. 2021, 11, 6602. [CrossRef]

31. Sadowska, J.; Dudzińska, W.; Skotnicka, E.; Sielatycka, K.; Daniel, I. The Impact of a Diet Containing Sucrose and Systematically Repeated Starvation on the Oxidative Status of the Uterus and Ovary of Rats. Nutrients 2019, 11, 1544. [CrossRef] [PubMed]

32. Stuper-Szablewska, K.; Rogoziński, T.; Perkowski, J. Contamination of pine and birch wood dust with microscopic fungi and determination of its sterol contents. Arch. Ind. Hyg. Toxicol. Rep. 2017, 68, 127-134. [CrossRef]

33. Szwajkowska-Michałek, L.; Rogoziński, T.; Stuper-Szablewska, K. Sterol content in bark after high-temperature drying of wood in convection driers. Sylwan 2019, 163, 610-616.

34. Chang, Y.L.; Wang, J.H. A Study of the Optimal Condition for the Growth of Aspergillus niger (BCRC 31494, ATCC 10864). In Proceedings of the 2018 BEST Conference \& International Symposium on Biotechnology and Bioengineering (BEST 2018), Taipei, Taiwan, 28-30 June 2018.

35. Leppänen, H.K.; Nevalainen, A.; Vepsäläinen, A.; Roponen, M.; Täubel, M.; Laine, O.; Rantakokko, P.; Mutius, E.; Pekkanen, J.; Hyvärinen, A. Determinants, reproducibility, and seasonal variation of ergosterol levels in house dust. Indoor Air 2014, 24, 248-259. [CrossRef]

36. Gessner, M.O. Ergosterol as a Measure of Fungal Biomass. In Methods to Study Litter Decomposition; Bärlocher, F., Gessner, M., Graça, M., Eds.; Springer: Berlin/Heidelberg, Germany, 2020; pp. 247-255.

37. Zhang, H.; Wolf-Hall, C.; Hall, C. Modified microwave-assisted extraction of ergosterol for measuring fungal biomass in grain cultures. J. Agric. Food Chem. 2008, 56, 11077-11080. [CrossRef]

38. Barreira, J.C.M.; Oliveira, M.B.P.P.; Ferreira, I.C.F.R. Development of a Novel Methodology for the Analysis of Ergosterol in Mushrooms. Food Anal. Methods 2014, 7, 217-223. [CrossRef]

39. Kulik, T.; Stuper-Szablewska, K.; Bilska, K.; Buśko, M.; Ostrowska-Kołodziejczak, A.; Załuski, D.; Perkowski, J. trans-Cinnamic and Chlorogenic Acids Affect the Secondary Metabolic Profiles and Ergosterol Biosynthesis by Fusarium culmorum and F. graminearum Sensu Stricto. Toxins 2017, 9, 198. [CrossRef]

40. Perkowski, J.; Buśko, M.; Stuper, K.; Kostecki, M.; Matysiak, A.; Szwajkowska-Michałek, L. Concentration of ergosterol in small-grained naturally contaminated and inoculated cereals. Biologia 2008, 63, 542-547. [CrossRef]

41. Szablewski, T.; Szwajkowska-Michałek, L.; Pędzik, M.; Rogoziński, T.; Stuper-Szablewska, K. Contamination with microscopic fungi measured by the concentration of ergosterol in dusts of various types of wood with different granulation. Annals of WULS -SGGW. For. Wood Technol. 2021, 113, 98-103. [CrossRef]

42. Mishra, G.; Panda, B.K.; Ramirez, W.A.; Jung, H.; Singh, C.B.; Lee, S.H.; Lee, I. Research advancements in optical imaging andspectroscopic techniques for nondestructivedetection of mold infection and mycotoxins incereal grains and nuts. Compr. Rev. Food Sci. Food Saf. 2021, 20, 4612-4651. [CrossRef] 
43. Stratil, P.; Klejdus, B.; Kubán̆, V. Determination of phenolic compounds and their antioxidant activity in fruits and cereals. Talanta 2007, 71, 1741-1751. [CrossRef]

44. Pourreza, N. Phenolic compounds as potential antioxidant. Jundishapur J. Nat. Pharm. Prod. 2013, 8, 149. [CrossRef]

45. Szwajkowska-Michałek, L.; Przybylska-Balcerek, A.; Rogoziński, T.; Stuper-Szablewska, K. Phenolic Compounds in Trees and Shrubs of Central Europe. Appl. Sci. 2020, 10, 6907. [CrossRef]

46. Wood, R. (Ed.) Active defense mechanisms in plants. In Springer Science \& Business Media; Published in cooperation with NATO Scientific Affairs Division, Plenum Press: New York, NY, USA; London, UK, 2012; Volume 37.

47. Rogoziński, T.; Szwajkowska-Michałek, L.; Dolny, S.; Andrzejak, R.; Perkowski, J. Assessment of microfungal contamination of dust generated during wood processing in furniture factories. Med. Pr. 2014, 65, 705-713.

48. Očkajová, A.; Stebila, J.; Rybakowski, M.; Rogozinski, T.; Krišták, L.; L'uptáková, J. The Granularity of Dust Particles when Sanding Wood and Wood-Based Materials. AMR 2014, 1001, 432-437. [CrossRef] 